\title{
THE ROYAL VISIT - Prince Philip accepts his certificate
}

These extracts from the BDJ were published on 18 March 1958 in Volume 104.

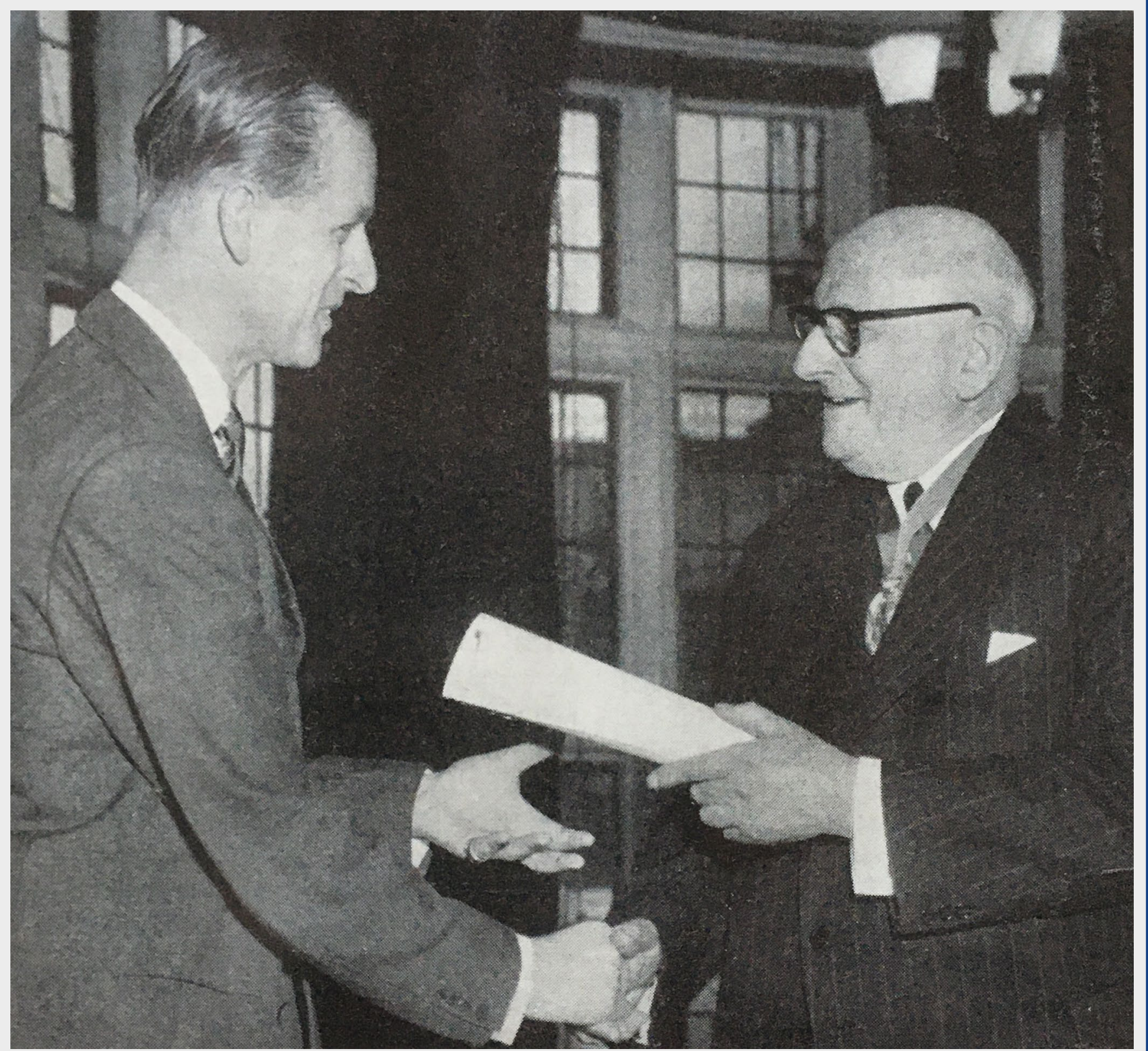

The Duke of Edinburgh paid his promised visit to our Headquarters on Tuesday, February 25, to receive his certificate of honorary membership of the Association. The occasion was widely reported in the National and Provincial Press and by the BBC.

The weather could just not have been worse. It had been snowing all night and showed little signs of stopping before our distinguished visitor was due to arrive. It prevented some of our friends and colleagues from attending the ceremony but everyone who could possibly make it arrived in good time.

February 25 was indeed a memorable day for all of us in the dental profession. It seems a long way back to that annual conference at the Dome, Brighton, when the recommendation of the Representative Board electing His Royal Highness The Duke of Edinburgh as an honorary member of the Association was passed with acclaim.

Yet it was only a little under two years ago. The motion stands in the minute book dated June 26, 1956. Since that time the officers of the Association have been in consultation with Buckingham Palace officials to arrange a suitable date when the Duke could receive the Certificate of Honorary Membership in a personal ceremony. On one occasion His Royal Highness had expressed a desire to visit our headquarters in Hill Street, which he had heard were both beautiful and interesting. 
14 Arrangements were made to find a date agreeable and finally February 25 was decided. The Duke honoured us by consenting to take lunch with us and look over our headquarters as well as receive his Certificate personally.

An immense amount of hard work and detailed planning was necessary by the staff at Hill Street prior to the date to make the occasion worthwhile. Although the Association has enjoyed Royal patronage through four reigns this is the first occasion that Royalty has visited our 'home'.

Invitations were sent out a few days beforehand. The Presidents of Branches and all the members of the Representative Board were included, together with half a dozen official guests. Caterers were called in to arrange the buffet lunch in the Board Room; the Chairman's rostrum and platform were removed and replaced temporarily by a small table and two gilt chairs. Flowers were arranged carefully and the Board Room transformed with snowy napery and gleaming silverware.

By midday a hundred and more members were gathered in the library, talking and smoking. Members of the secretariat briefed those selected to be presented to His Royal Highness as to where they were to stand, either in the main Hall or in the Board Room.

Our visitor was due at a quarter to one. We knew there had been an investiture at the Palace that morning; even so that, plus the appalling weather, only held the Duke up for a matter of minutes. The staff were gathered on one side of the staircase; the principal officers of the Association stood in the Hall to greet His Royal Highness together with photographers, their cameras and flashlights at the ready.

\section{The Duke Arrives}

At ten to one the policemen on the door came to attention and moved forward. The Royal car had arrived. The Duke stepped out, hatless and without a great coat, to shake hands heartily with the Secretary who immediately introduced him to our President, $\mathrm{Mr}$ Harry Davis.
In the main hall His Royal Highness shook hands with Mr William Peebles, Chairman of the Representative Board, Mr Lionel Balding, Chairman of Council, $\mathrm{Mr}$ Jack Gilbert, Honorary Treasurer, Mr W. Stamford Brittan, Vice-Chairman of the Representative Board and Mr J. P. Cocker, Vice-Chairman of Council.

The presentations over the Duke had a brief word with Mr Davis and Mr Peebles before following the President up the free side of the great staircase to the Board Room. He had a cheerful smile for the feminine staff gracing the other side of the stairway before he entered the Board Room where further presentations took place.

Those presented here were: Dr Liliam Lindsay, Sir Wilfred Fish, Professor R. V. Bradlaw, Surgeon Rear-Admiral (D) C. J. Finnigan, Mr A. H. Condry, Mr J. Chalmers and Mr J. V. Bingay.

\section{The Presentation}

After the presentations Mr Davis led the Duke to the dais and we stood in the body of the hall to await the short ceremony of presentation of the Certificate. After receiving the scroll our new Honorary Member made a short reply to Mr Davis's speech of welcome, emphasising his pleasure at being present. The ceremony being completed the meeting became more informal. Photographers packed their kit away and the caterers' staff appeared as if by magic to handle the buffet. The Duke, the President and a few of the senior officers had their private table at the head of the Board Room. The Duke paid us one of the nicest compliments by wearing the BDA tie.

The lunch was a memorable success and, also, too soon ended. Just after two o'clock the President and the Secretary escorted the Duke and Mr J. B. V. Orr to the museum on the second floor. There they were shown the old dental chairs, pictures and other items; the Duke was particularly interested in the history of the chairs and discussed for a few minutes the possibilities of the old wooden 'barber's chair' having ever been used as a dental chair, and whether it really was three hundred years old or just a clever imitation and of no particularly great vintage.

He showed a keen interest in the dental chair designed and built for King Edward VII and which, on that monarch's death, was presented by Buckingham Palace to the British Dental Association. He noted the short seat, the long back and the mechanism to adjust the seat.

After spending some time in this section Mr Davis led the party to the third floor where he presented Mr J. A. Donaldson, the Honorary Curator. The glass fronts of the display cases had been removed so that the Duke was able to handle any of the instruments that took his fancy. The Curator had spent a good deal of time during the last few weeks

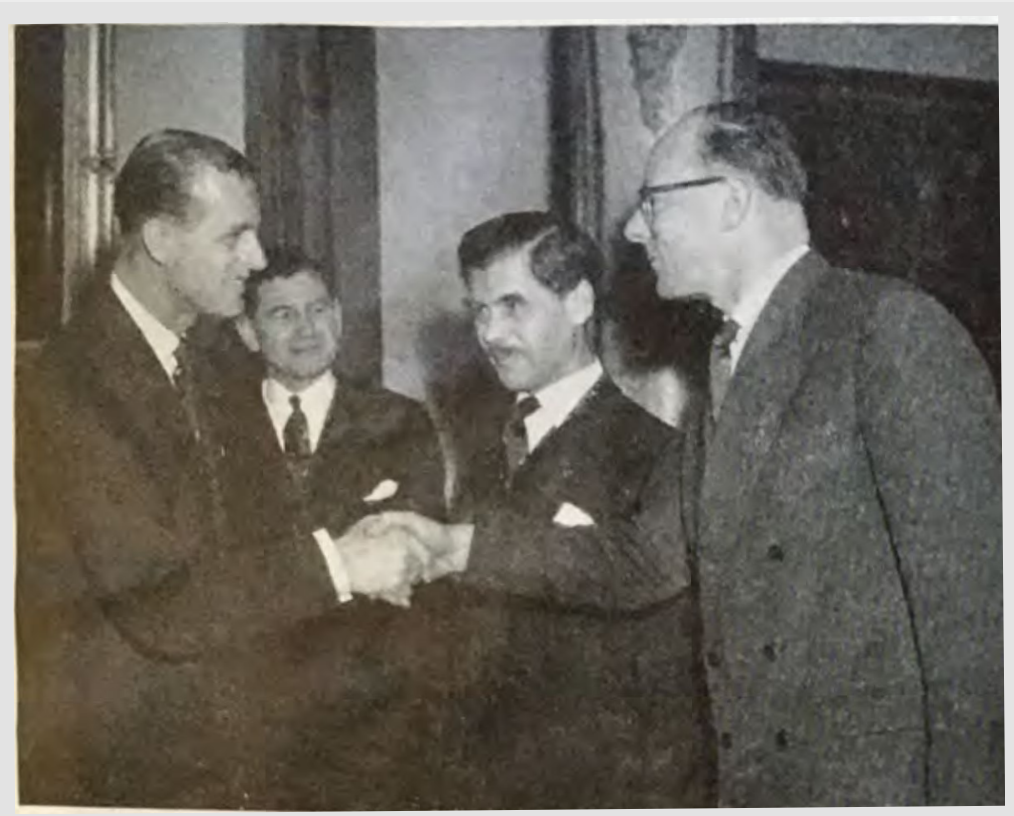


1 rearranging the exhibits so they would show up to better advantage.

His Royal Highness stayed in the Museum for about ten minutes, admiring the exhibits and discussing points with the President and $\mathrm{Mr}$ Donaldson, who was able to show the Duke how the Association's collection gave a comprehensive survey of the development of dentistry. The old instruments of the first decades of the Association's existence (some used by our professional forebears) were displayed so as to make plain the progressive application of skill and ingenuity to the advance of dental art and technique.

\section{The Farewell}

All good things must come to an end, however. Our guest had other appointments and shortly after half past two he and his equerry were downstairs in the main hall bidding us all farewell. As he came down the broad staircase, members lining it on each side and applauding him, here happened one of those small incidents which can make an occasion already memorable, unforgettable. One member started to sing "For He's a Jolly Good Fellow." Within seconds it had been taken up by others, singing lustily.

At the door the Duke turned, smiled and waved to us all. We felt that he had enjoyed his visit enormously; that all the planning, hard work - and overtime had been more than worth the while.

M. H.

\section{MORE TEACHING FACILITIES NEEDED}

\section{President's Speech at Ceremony}

The President said: Your Royal Highness, by so graciously accepting Honorary Membership of the British Dental Association, has given very great pleasure to all British dental surgeons both in the United Kingdom and throughout the Commonwealth.

This historic occasion will be so proudly recorded in the annals of the Association and each member privileged to be here will always remember this as one of the outstanding events of his professional life.
The British Dental Association, which represents every aspect of dentistry, has enjoyed Royal Patronage throughout four reigns, a distinction which we treasure and which ever reminds us that our aims must be in keeping with the highest traditions of integrity and service.

We are most grateful for the very real interest which you, Sir, have always shown in the health of the public, particularly in the physical wellbeing of young people as has been so clearly demonstrated by your patronage of the National Playing Fields Association and the Outward Bound Schools. We of the British Dental Association have long been active in dental health education, believing that prevention is better than cure; indeed, one of the earliest reports published by this Association over seventy years ago embodies the statement that the greatest contribution a dentist can make to the welfare of mankind is to care for the teeth of children.

Dental disease in this country has long been a serious and crippling problem from both the national and the individual point of view. In spite of the enormous advances which have been made in dental science and technique, it is a fact that over half a million man-hours are still being lost yearly in industry through the ravages of dental disease.

Our greatest problem today is to increase teaching facilities in the dental schools so that a sufficient number of fully qualified dental surgeons may be trained to keep

pace with the increased demand for dental treatment. This need for more and bigger dental schools is a matter about which we find it hard to control our impatience. Until we have an adequate number of dentists we cannot achieve what we are striving for - dental health for all.

To strike a more personal note, may I point out to Your Royal Highness that the Certificate of Honorary Membership which we have so much pleasure in presenting to you today does not entitle you to follow the example of your illustrious ancestor, King James IV of Scotland, who had the enviable reputation of being highly skilled in the art of extracting teeth. On the other hand, Sir, this Certificate may perhaps fortify you - and your patient - should you ever hear that distant, plaintive cry which so many of us, as fathers, sometimes hear, and which usually comes in the evening when we are about to leave for an important engagement - 'Daddy, I've got a loose tooth.'

Your Royal Highness, it is my proud privilege to present to you this, your Certificate of Honorary Membership of the British Dental Association.

\section{'NOW IT IS MY TURN' \\ SAYS THE DUKE}

Thank you very much indeed for the kind welcome and for the Certificate of Honorary Membership. There is one great disappointment though, and that is that you have now told me I am not allowed to practise. This is the first time that I was looking forward to my next visit to my dentist; when he had finished I was proposing to say 'Now it is my turn!'

Incidentally, it is just as well that there are no certificates for patients because I simply don't deserve one. I very seldom go, and then it needs, or very nearly needs, a general anaesthetic to get me in and I must admit that at the time I am not always appreciative of the efforts of the dental surgeon.

I must confess that my dental biography, so to speak, is rather uneventful. I went through the usual process as a boy of having a lot of holes drilled in my teeth and then filled up again for some reason best known to the dentist. I can only claim two dental dramas: I had a tooth knocked out while playing ice hockey on roller skates with bicycle polo sticks, and I broke a tooth eating a Maltese chicken while I was in the Navy. All I can add to that is a visit to the dentist in Florence and Monaco and that seems to be the sum total of my dental experience, so that it is obvious that I am not accepting this Certificate as a star patient or some dental freak, and I want to make it quite clear that I never expected to be asked to become an Honorary Member of this Association.

I have accepted it not only for myself but for all your patients, and for all those people young and old who have been able to live a pleasanter and healthier life as a result of your care and skill.

Thank you very much indeed. 